\title{
Time consumption and productivity of a medium size mobile tower yarder in downhill and uphill configurations: a case study in Czech Republic
}

\author{
Andrea Rosario Proto, ${ }^{1}$ Alois Skoupy, ${ }^{2}$ Giorgio Macri, ${ }^{1}$ Giuseppe Zimbalatti ${ }^{1}$ \\ ${ }^{1}$ Department of Agriculture, Mediterranean University of Reggio Calabria, Italy \\ ${ }^{2}$ Department of Forest and Forest Products Technology, Mendel University, Brno, Czech Republic
}

\begin{abstract}
Cable cranes are among the most important means of yarding and transporting timber in many mountainous regions of Europe. In the last decade, all-terrain mobile tower cable cranes have been increasing due to their adaptability to operate both in uphill as well in downhill configuration. This research assesses the efficiency and the costs of a mobile cable crane manufactured in Czech Republic and designed for all-terrain application and specifically mounted on a wheeled agricultural tractor. A total of 100 cycle times were recorded in order to obtain evaluate the performance in the downhill as well uphill extraction configuration. The productivity analysis was based on regression equation as a function lateral distance, skyline slope distance and extracted volume. Increasing in number of lateral distance and extraction distance resulted as significant variables affecting the cycle time. Even if the test highlights a good efficiency of the extraction system for both the configuration (uphill $v s$ downhill) there a still many organisational features that could be improved in order to fully exploit the potentiality of the tested cable crane system.
\end{abstract}

\section{Introduction}

Cable yarding has been used extensively in Central Europe since the 1970 s when mobile integrated tower yarders were introduced (Heinimann et al., 2001). Nowadays it is well recognised that cable

Correspondence: Andrea Rosario Proto, Department of Agriculture, Mediterranean University of Reggio Calabria, loc. Feo di Vito I, 89122 Reggio Calabria, Italy.

Tel.:+39.0965.1694275.

E-mail: andrea.proto@unirc.it

Key words: Mobile cable crane; forest operations; cable extraction; steep terrain; Czech Republic.

Received for publication: 1 March 2016.

Accepted for publication: 17 October 2016.

(C) Copyright A.R. Proto et al., 2016

Licensee PAGEPress, Italy

Journal of Agricultural Engineering 2016; XLVII:551

doi:10.4081/jae.2016.551

This article is distributed under the terms of the Creative Commons Attribution Noncommercial License (by-nc 4.0) which permits any noncommercial use, distribution, and reproduction in any medium, provided the original author(s) and source are credited. yarding represents a low impact system for extracting wood in steep terrain both on soil as well on residual stand trees (Stampfer et al., 2006). Again, on steep terrain, cable yarding could be a cost-effective alternative to building an extensive network of skidding trails and results in a much lower site impact compared to ground-based logging (Worrell et al., 2011; Stanczykiewicz et al., 2015), as well it seems to be competitive in terms of $\mathrm{CO}_{2}$ in comparison to semi-mechanised ground-based logging (Cosola et al., 2016).

During the last ten years, new cable crane models have been developed for applications in conditions where the terrain prohibits the use of other techniques. A recent study highlights that the annual utilisation of cable yarding systems in Austria is between 560 and $1500 \mathrm{~h}$ productive machine hours (Holzleitner et al., 2011).

All-terrain mobile tower cable cranes are one of the promising innovations; all-terrain system can operate under different terrain characteristic (steepness, soil wet condition, etc.) independently from the extraction direction (Heinimann et al., 2001). Cable cranes with universal carriages are not limited to a narrow working area and they can be very efficient in locations where other forms of wood extraction are not possible or permissible due to various natural or ecological limitations (Klun et al., 2005). Anyway in the last decades more than 50 works have analysed the efficiency and the impact of cable yarder (Cavalli, 2012) highlighting the strong interest of the scientific community on the topics.

The purpose of this study is to investigate the productivity of mobile cable cranes mounted on a 4WD agricultural tractor, which has been occasional, investigated till now with the aim to evaluate the significant variables affecting the extraction operation efficiency.

\section{Materials and methods}

\section{Cable yarder unit}

The tested mobile cable crane is the Larix Lamako, which is a mobile cable crane, designed for extracting wood downhill as well as uphill. The system can be classified as a four rope-system as it comprises a skyline, a mainline, a haul-back line and an assembly line (Table 1). The cable crane is designed with a super structure, which is mounted on the rear three-point linkage (tower with winches) and on the front three-point linkage (storage drums, assembly drum, and carriage) of an agricultural $4 \mathrm{WD}$ tractor. The total mass $(11,200 \mathrm{~kg}$ ) (tractor and cable crane) is distributed for $70 \%$ on rear axle of tractor and the complete unit is also very mobile on difficult terrain (Kovácik and Stoilov, 2009; Klva et al., 2012). The acronym of this system Lamako means lanovka pro malékoncentrace (standing skyline yarding system for small wood densities) and it was introduced in 2008 (Kovácik and Stoilov, 2009). The carriage is a MM-Sherpa U3t in a 3-cable system configuration (Mayr-Melnhof Forsttechnik GmbH, 2009) (Figures 1 and 2). The clamps of the carriage are controlled by a remote system 
device, which gives the advantage, that the carriage can be stop and blocked at any position along the skyline. The mainline is mechanically slack pulled to the logs by using the power of the haul-back line winch while the skyline clamp is active. The MM-Sherpa U3t carriage has a suitable haul-back line drum capacity for the lateral yarding distance. The logs are yarded laterally to the carriage using the power of the yarder's mainline winch and active skyline clamps (Proto and Zimbalatti, 2015).

\section{Study site and work organisation}

The case study was situated in the Krtiny Training Forest Enterprise in the municipality of Brno at an altitude of about $400 \mathrm{~m}$ a.s.l. (Hurt $e t$ al., 2014) (Figure 3). The area covered about 6 ha with a $\mathrm{N}-\mathrm{O}$ exposition. The Larix Lamako was used in two spruce (Picea abies L.) stands (sites A and B, Table 2) where site A was located downhill from the main access road (wood is here yarded uphill to the road), whereas site B was uphill of the main trail (wood is here yarded downhill to the road). Selective cut was adopted and was removed $20 \%$ of volume per hectare in both sites. The operating area of the cable crane was about 1.46 ha at site $\mathrm{A}$ and 1.05 ha at site $\mathrm{B}$, where the differences in hight between the two extremities of the line were $32 \mathrm{~m}$ at site A and $23 \mathrm{~m}$ at site $B$. The two stands were quite similar and the operators worked in the same manner during both tests and in both areas (A and B). A single span line was mounted and two supports were used to hold the haul-back line off the ground in both sites. The tower was stabilised with four guy lines fixed around anchor trees.

The tree-length system, which consists in felling, delimbing and top-

Table 1. Technical characteristics of the cable crane.

\begin{tabular}{|c|c|}
\hline Characteristics & Larix Lamako \\
\hline $\begin{array}{l}\text { Tower } \\
\text { - } \quad \text { Type } \\
\text { - } \quad \text { Height }(\mathrm{m})\end{array}$ & $\begin{array}{c}\text { Hinged } \\
8\end{array}$ \\
\hline $\begin{array}{ll}\text { Guylines } \\
- & \text { Number } \\
- & \text { Diameter }(\mathrm{mm}) \\
- & \text { Length }(\mathrm{m}) \\
- & \text { Pulling force }(\mathrm{kN}) \\
\end{array}$ & $\begin{array}{c}6 \\
10 \\
200 \\
6\end{array}$ \\
\hline $\begin{array}{ll}\text { Winch } \\
\text { - } & \text { Main line drum capacity (m) } \\
\text { - } & \text { Diameter of mainline (mm) } \\
\text { - } & \text { Main line pulling force }(\mathrm{kN}) \\
\text { - } & \text { Skyline drum capacity }(\mathrm{m}) \\
\text { - } & \text { Diameter of skyline (mm) } \\
\text { - } & \text { Skyline cable tensioning force }(\mathrm{kN}) \\
\text { - } & \text { Haul-back line drum capacity (m) } \\
\text { - } & \text { Diameter of mainline (mm) } \\
\text { - } & \text { Main line pulling force (kN) }\end{array}$ & $\begin{array}{c}550 \\
10 \\
27 \\
550 \\
16 \\
45 \\
\\
1100 \\
10 \\
20\end{array}$ \\
\hline Engine power (kW) & $70+$ \\
\hline $\begin{array}{l}\text { Weight total }(\mathrm{kg}) \\
-\quad \text { Loading rear axle of tractor }(\mathrm{kg}) \\
-\quad \text { Loading front axle of tractor }(\mathrm{kg})\end{array}$ & $\begin{array}{l}4100 \\
3000 \\
1100\end{array}$ \\
\hline $\begin{array}{ll}\text { Carriage } \\
\text { - } & \text { Type } \\
\text { - } & \text { Model } \\
\text { - } & \text { Size }(\text { width } \times \text { depth } \times \text { height }-\mathrm{cm}) \\
\text { - } & \text { Weight }(\mathrm{kg}) \\
\text { - } & \text { Safety brake } \\
\text { - } & \text { Loading capacity }(\mathrm{kN})\end{array}$ & $\begin{array}{c}\text { Automatic } \\
\text { MM- Sherpa U3t } \\
203 \times 46 \times 105 \\
453 \\
\text { Present } \\
30\end{array}$ \\
\hline
\end{tabular}

ping trees at the stump area was used in both the cases (Table 2). The logs were then transported to the landing where they were bucked and loaded into a truck. The volume of each tree was calculated using Smalian's formula by multiplying the average cross-sectional area of the stem by the stem length (Philip, 1994). The lengths of timber ranged from 14 to $17 \mathrm{~m}$. At sites $\mathrm{A}$ and $\mathrm{B}$, teams of 4 operators were working in the timber-yard: a yarder operator, two choker setters, and an operator for timber unloading.

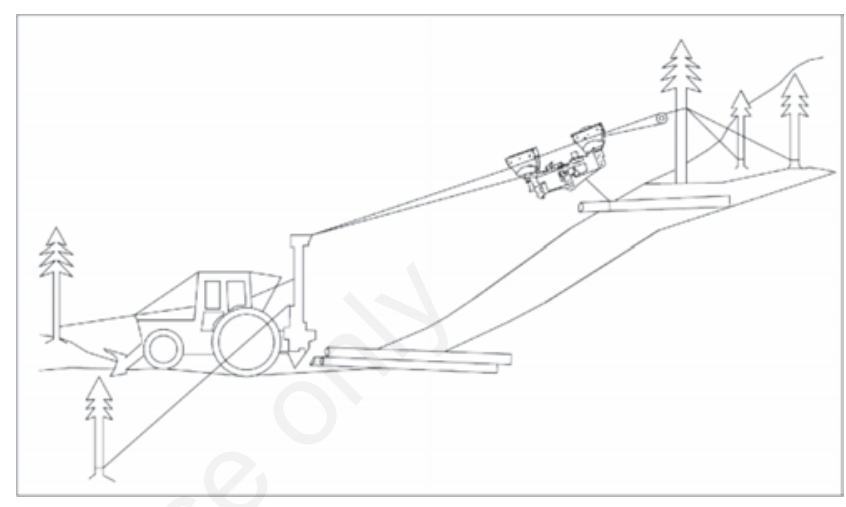

Figure 1. Setting of the cable crane while working at site A.

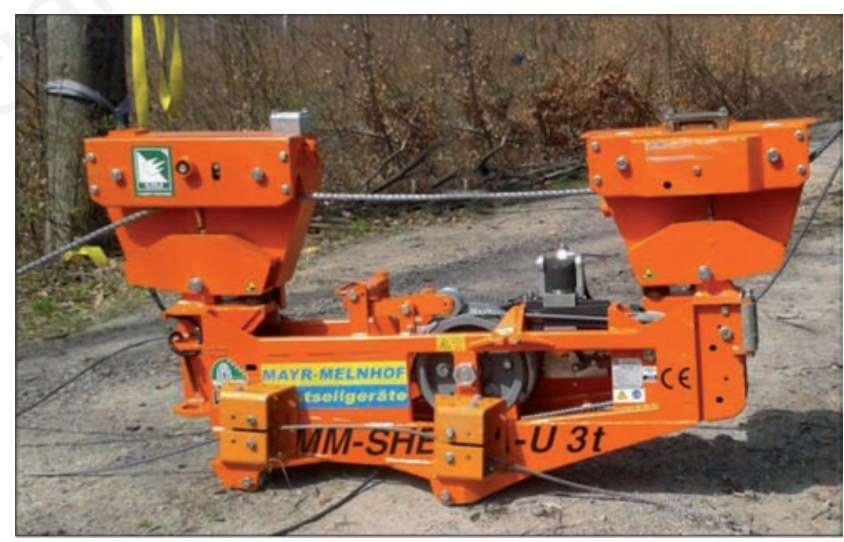

Figure 2. MM-Sherpa U3t Carriage.

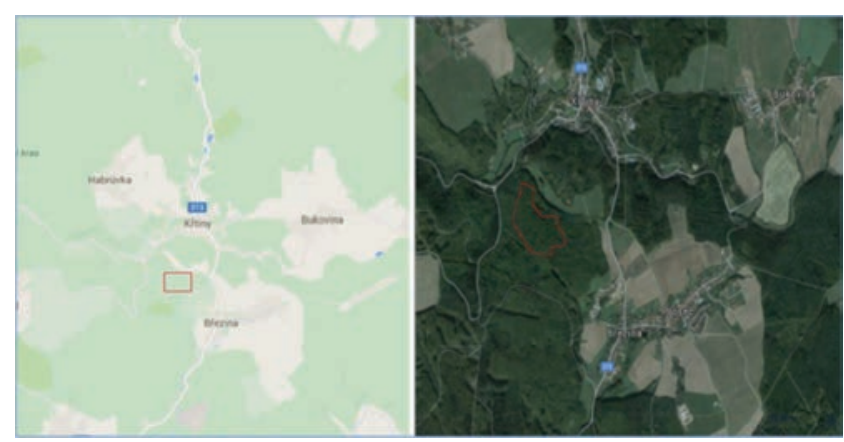

Figure 3. Krtiny Training Forest Enterprise in Brno province and the felling area. 


\section{Time consumption and productivity study}

Similar to other studies to determine the performance and cost of cable yarding technology, this study analysed time consumption data using the general concepts employed in observational modelling studies (Aykut, 1986; Zimbalatti and Proto, 2009; Spinelli et al., 2010; Borz et al., 2014). The time and motion study was conducted using the repetition timing method to determine the total yarding cycle time, i.e., the amount of time required for the carriage to travel from the landing until the unhooking of the payload. These activities were investigated in terms of the cycle times by using stopwatches for each individual cycle, where we separated the productive time from the delay time, as well as identifying the variables that were most likely to affect the time consumption (Balimunsi et al., 2012). Six yarding elements were identified and timed to determine the total cycle time (Huyler and Ledoux, 1997):

Outhaul empty: begins when the operator is ready to move the carriage from the landing out to choke setter and ends when the choke setter touches the choke.

Lateral out: begins at the end of outhaul empty and ends when the choke setter is ready to hook a turn (Choke setter's forward motion has stopped and is ready to begin setting the chokers).

Hook up: begins at the end of lateral out and ends when the choke setter has completed hooking the chokers and signals to begin yarding.

Lateral in: begins at the end of hook up and ends when the turn is pulled up to the carriage and the carriage begins to move up the corridor.

In haul: begins at the end of lateral in and ends when the turn has reached the position on the deck where it can be directly unhooked at the landing.

Unhook: begins at the end of in haul and ends when the chokers have returned to the carriage.

In practice, 100 cycle times were recorded in total to determine the average performance at each site (A and B). The time data were recorded by two researchers, i.e., one stationed with the timber at the bunching location and the other stationed next to the cable system. Wireless communication was maintained between these researchers. During the trials, the Larix Lamako was operated by the remote control, both from the landing and the stand (when setting the chokers). The in hauland the out haul functions of the drums were synchronised by computer, so the operators only used simple orders to control the yarder (Kovácik and Stoilov, 2009).

The machine costs were calculated as described by Miyata (1980) for forest machine and by using the COST model proposed by Ackerman et al. (2014). In order to calculate the production cost for $1 \mathrm{~m}^{3}$ of wood, the cost analysis employed the following parameters: the number of operators, the hourly cost of an operator, the hourly cost of machines, the volume of wood extracted, and productive machine hours excluding all delay times. The machine costs per hour were reported both as productive machine hours excluding delays and scheduled machine hours. The purchase prices and operator wages required by the cost calculations were obtained from catalogues and accounting records.

\section{Data analysis}

We measured the impact of the following independent variables on the total cycle time (total time). We used the total cycle time as a dependent variable whereas lateral distance, skyline slope distance and volume were selected as independent variables.

The definitions of independent variables as well as their measurements are summarised as follows:

Lateral distance: the lateral yarding distance was measured either by pacing the distance or by ocular estimation of the distance to the nearest $10 \mathrm{~m}$.
Skyline slope distance: on each corridor, the ground slope distance was measured by tape meter and marked at regular intervals to aid in recording slope distance that the carriage travelled during the study period.

Volume: each log in the corridor was measured by caliper and tape meter and marked with an identification number and recorder by turn number. The volume was determined according to the Huber's Formula.

All of previous independent variables were considered and included the following theoretical equation:

Total cycle time $=\mathrm{f}$ (Dir_Dummy, Lateral distance,

Skyline slope distance, Volume)

where Dir_Dummy $=1$ for Uphill and 0 for downhill.

A spreadsheet was compiled with the collected data and used then in the SPSS software for the statistical analysis. A regression model was thus developed. Initially, a 95\% significance level was set to test the null and alternative hypotheses given above. An F-test (variance analysis) was used thus to test whether the data satisfied the statistical model, i.e., F-test $=7.88$ which were statistically significant at $\mathrm{P}<0.005$.

\section{Results and discussion}

The average timber haulage times for the Larix Lamako were 8.45 min at site A and 9.11 min at site B (Table 3). Regression analysis was performed on the Larix Lamako time study data to develop a delay free cycle time equation for the machine under the stand conditions stated in the study. The variables included skyline slope distance, lateral distance and volume per turn.

The volume of an average piece of timber was $0.30 \mathrm{~m}^{3}$ and its length was $15 \mathrm{~m}$ at site A. At site B, the volume of an average piece of timber was $0.24 \mathrm{~m}^{3}$ and it measured $14 \mathrm{~m}$. The total volumes were $163 \mathrm{~m}^{3}$ at site $A$ and $111 \mathrm{~m}^{3}$ at B, i.e., $112 \mathrm{~m}^{3} \mathrm{ha}^{-1}$ for site $\mathrm{A}$ and $106 \mathrm{~m}^{3} \mathrm{ha}^{-1}$ for site B. On average, daily productivity per operator was $6.02 \mathrm{~m}^{3}$ day-1 at site $A$ and $4.96 \mathrm{~m}^{3}$ day $^{-1}$ at site $\mathrm{B}$. The difference between the two sites (A and B) was directly dependent on the extraction distance and the volume of each load. In Figure 4 data from individual cycle observations

Table 2. Characteristics of the test sites.

$\begin{array}{cc}\text { Area } & \text { Work site A Work site B } \\ \text { Masaryk Forest Krtiny }\end{array}$

Altitude (m a.s.l.)

550

490

Forest

Species

Silvicultural system

Stand density (trees ha $\left.^{-1}\right)$

Total volume $\left(\mathrm{m}^{3} \mathrm{ha}^{-1}\right)$

Average slope (\%)

Average lateral pull (m)

Yarding direction

Roughness

Spruce

High forest

725

Spruce

Selective cut

Length of line (m)

558

48

Difference in height between the two

ends of the line

Average sag (m)

43

28

$43 \quad 35$

$\begin{array}{cc}\text { Uphill } & \begin{array}{c}\text { Downhill } \\ \text { Average }\end{array} \\ 195 & 180 \\ 32 & 23 \\ & \\ \end{array}$

3.15 
were analysed with regression technique in order to calculate relationship between productivity and distance.

The length of the logs influenced the time required for extraction and bunching at both sites. In fact, the number of logs in each load (two or three in the most of the cases) and the speed of the transport were restrained in order to reduce residual stand damage. The average delay time was $0.28 \mathrm{~min} /$ cycle. The lost time occurred during the loading and unloading of the carriage. Our evaluations of efficiency in organisa-

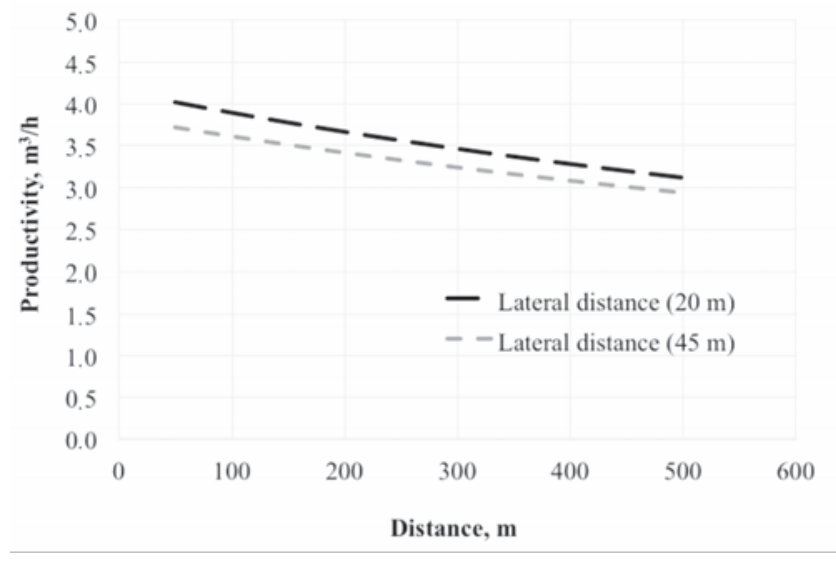

Figure 4. Relationship between productivity and extraction distance. tional and economical terms showed that for the Larix Lamako machine, the volume harvested per field length of cable line was 0.84 $\mathrm{m}^{3} \mathrm{~m}^{-1}$ at site A and $0.65 \mathrm{~m}^{3} \mathrm{~m}^{-1}$ at site $\mathrm{B}$. This indicator assessed the relationship between the total volume of yarded trees and the field length of the cable crane line. The mounting and dismounting of this cable crane was easy, fast and the productivity was low influenced (Table 4). An important factor that restricted the bunching and extraction times at both sites was the harvesting method. The maximum lat-

Table 3. Time consumption ( $\mathrm{min} \pm$ standard deviation) per working component.

\begin{tabular}{llcc} 
Phases & \multicolumn{3}{c}{ Larix Lamako } \\
\multirow{3}{*}{ Outhaul empty } & Min & 1.65 & 1.84 \\
& (SD) & $(0.16)$ & $(0.80)$ \\
Lateral out + hook up + lateral in & Min & 2.95 & 2.80 \\
& (SD) & $(0.44)$ & $(0.44)$ \\
\hline In haul & Min & 3.30 & 3.35 \\
& (SD) & $(0.18)$ & $(0.18)$ \\
Unhook & Min & 0.31 & 0.34 \\
& (SD) & $(0.05)$ & $(0.05)$ \\
\hline Delay time & Min & 0.24 & 0.30 \\
& (SD) & $(0.04)$ & $(0.04)$ \\
Total & Min & 8.45 & 9.11 \\
& (SD) & $(0.36)$ & $(0.69)$ \\
\hline
\end{tabular}

SD, standard deviation.

(SD)

$0.36)$

Table 4. Average daily operating results at the work sites.

\begin{tabular}{|c|c|c|c|}
\hline \multirow[b]{2}{*}{ Wood harvest systems } & \multirow{2}{*}{$\begin{array}{c}\text { Unit } \\
\text { Tree length system }\end{array}$} & \multicolumn{2}{|c|}{ Larix Lamako } \\
\hline & & Work site A & Work site B \\
\hline Number of valid observations & n. & 100 & 100 \\
\hline Total duration of observations without mounting and dismantling times & $\mathrm{h}$ & 17.39 & 19.51 \\
\hline $\begin{array}{ll}\text { Yard cycles } \\
\text { - } & \text { Average volume per cycle } \\
\text { - } & \text { Yarding cycle per day } \\
\text { - } & \text { Yarding cycle per hour } \\
\text { - } & \text { Average time for one cycle } \\
\text { - } & \text { Standard deviation }(\sigma) \\
- & \text { Coeff. of variation }\end{array}$ & $\begin{array}{l}\mathrm{m}^{3} \\
\mathrm{n} . \\
\mathrm{n} . \\
\text { Min. } \\
\pm \\
\%\end{array}$ & $\begin{array}{l}0.52 \\
46 \\
6 \\
8.45 \\
0.36 \\
4.28\end{array}$ & $\begin{array}{c}0.48 \\
41 \\
5 \\
9.11 \\
0.69 \\
8.08\end{array}$ \\
\hline $\begin{array}{ll}\text { Productivity } \\
- & \text { Daily SMH } \\
- & \text { Daily PMH } \\
- & \text { Hourly SMH } \\
- & \text { Hourly PMH } \\
\end{array}$ & $\begin{array}{l}\mathrm{m}^{3} \mathrm{~d}^{-1} \\
\mathrm{~m}^{3} \mathrm{~d}^{-1} \\
\mathrm{~m}^{3} \mathrm{~h}^{-1} \\
\mathrm{~m}^{3} \mathrm{~h}^{-1}\end{array}$ & $\begin{array}{c}23.92 \\
29.52 \\
2.99 \\
3.69\end{array}$ & $\begin{array}{c}19.68 \\
23.84 \\
2.46 \\
2.98\end{array}$ \\
\hline 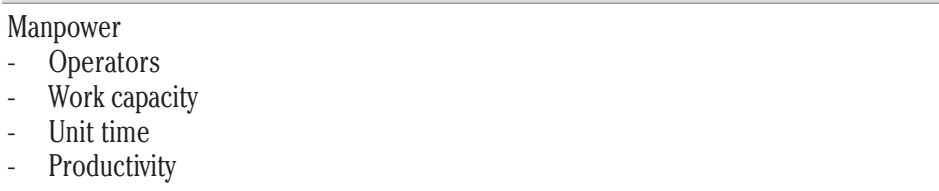 & $\begin{array}{c}\mathrm{n} . \\
\mathrm{m}^{3} \mathrm{~h}^{-1} \text {-man } \\
\mathrm{h} \mathrm{m}^{-3} \\
\text { h-man m } \mathrm{m}^{-3}\end{array}$ & $\begin{array}{c}4 \\
0.75 \\
0.33 \\
1.34\end{array}$ & $\begin{array}{c}4 \\
0.62 \\
0.41 \\
1.63\end{array}$ \\
\hline Incidence of mounting and dismantling times in 100 trips observed & $\mathrm{h}$ & 1.12 & 1.39 \\
\hline Total duration of observations including incidence of mounting and dismantling times & $\mathrm{h}$ & 18.51 & 20.90 \\
\hline Mounting and dismantling times & h & 3.50 & 2.70 \\
\hline $\begin{array}{ll}\text { Productivity } \\
- & \text { Volume per } 100 \text { cycles } \\
\text { - } & \text { Daily } \\
- & \text { Hourly } \\
\text { - } & \text { Unit time }\end{array}$ & $\begin{array}{c}\mathrm{m}^{3} \\
\mathrm{~m}^{3} \mathrm{~d}^{-1} \\
\mathrm{~m}^{3} \mathrm{~h}^{-1} \\
\mathrm{~h} \mathrm{~m} \mathrm{~m}^{-3}\end{array}$ & $\begin{array}{c}52 \\
22.48 \\
2.81 \\
0.36\end{array}$ & $\begin{array}{c}48 \\
18.57 \\
2.32 \\
0.43\end{array}$ \\
\hline
\end{tabular}


eral yard distance, i.e., $45 \mathrm{~m}$ at site $\mathrm{A}$ and $40 \mathrm{~m}$ at site $\mathrm{B}$, did not facilitate the bunching operations for trees when using the tree-length system. The lengths of timber ranged from 14 to $17 \mathrm{~m}$ and the travelling load was partially suspended, where it bumped into the lower parts of trees and the soil, which forced the operator to extract at a speed lower than the full potential of the carriage, despite directional felling was performed properly. Thus, the yarding of semi-suspended trees is only compatible with uphill extraction. Given the lengths of the trees extracted, it might be helpful to employ a different carriage respects MM-Sherpa U 3t that extracts long loads in a fully horizontal direction or to increase the distance of the skyline cable above the ground. Two independent operating hoisting winches mounted on the carriage, for example, could allow the horizontal transport of long and high loads even with a small distance between the skyline cable and ground. This could increase the speed of extraction and thus the productivity of the yard. The present study showed that the cable crane extracted lower average volumes of timber $\left(0.50 \mathrm{~m}^{3}\right)$ compared with the full load potential of the carriage. In particular, the use of a $1.5 \mathrm{t}$ carriage could be more appropriate in this place compared with the $3 \mathrm{t}$ load capacity of the carriage used. The limited average extracted volume recorded in this study may have depended on the work method employed rather than the machine capacity. It is known that the preparation of loads has an important effect on the efficiency of load extraction.

The fixed and hourly operating costs for the cable crane, included labour cost of four operators, are shown in Table 5. Using the Larix Lamako, the extraction costs for wood were calculated as $42.97 €$ per $\mathrm{m}^{3}$ at site $\mathrm{A}$ and $52.22 €$ at site $\mathrm{B}$, where these costs refer to the working time (productive + unproductive time). Thus, when the cable crane was productive, the extraction costs were $34.79 €$ per $\mathrm{m}^{3}$ at site $\mathrm{A}$ and $43.08 €$ at site B. The delay times increased the operating cost by $8 €$ (19\%) at site $A$ and $9 €(17 \%)$ at site $B$. The number of valid observa-

Table 5. Calculation of hourly costs of cable crane included four operators.

\begin{tabular}{lccc} 
Parameter & Value & Parameter & Value \\
Purchase price $(€)$ & 175,000 & Interest cost $(€)$ & 2742 \\
Salvage value $(€)$ & 35,000 & Taxes and insurance $(€)$ & 8773 \\
\hline Economic life $(\mathrm{y})$ & 15 & Total fixed cost $\left(€ \mathrm{~h}^{-1}\right)$ & 27.72 \\
Yearly utilisation $(\mathrm{n})$ & 160 & Total variable cost $\left(€ \mathrm{~h}^{-1}\right)$ & 17.75 \\
\hline Scheduled operating time $(\mathrm{h})$ & 1280 & Total labour cost $\left(€ \mathrm{~h}^{-1}\right)$ & 90.00 \\
Annual depreciation $(€)$ & 9333 & Total cost $\left(€ \mathrm{~h}^{-1}\right)$ & 128.47 \\
\hline
\end{tabular}

tions collected during the tests was large enough to develop reliable model for predicting cycle time. The cycle-time equation for the Larix Lamako tooks the following form:

Cycle Time $(\min )=7.005+0.026 *$ Lateral distance $(\mathrm{m})+0.005 *$ Skyline slope distance (m)

$\mathrm{R}^{2}=0.44$

The F-test (variance analysis) results were reported in Table 6. It is possible to observe how Lateral distance $(\mathrm{P}<0.001)$ and Skyline slope distance $(\mathrm{P}<0.005)$ showed a significant contributes, Dir Dummy (1) and Volume $(\mathrm{P}>0.005)$ had instead a non-significant contribute.

The productivity model was calculated with the significant variables of the equation of the total cycle time.

The utilisation rates determined by this study are not much different than those reported by Spinelli et al. (2010) in Italy for two tower yarder models and in Turkey by Ozturk and Senturk (2006) for uphill and downhill extraction of spruce timber. The test of the cable crane obtained satisfactory results but a number of organisational features could be improved in order to fully exploit its potential.

\section{Conclusions}

The objective of this study was to analyse the productivity of Larix Lamako in two different cases (downhill and uphill extraction configurations) using a time motion methodology. No significant differences in productivity were found between downhill and uphill extraction direction as well in terms of extracted volume. On the other hand, lateral distance and skyline slope distance show a significant effect on the productivity. The acquired data and the resulting analysis focused on the bunching operation since it is one of the most critical working elements of logging.

In conclusion, the possibility of applying agricultural tractors with a mobile cable crane system (downhill and uphill) may improve the spread of this method in small enterprises. The development of new tools and methods will allow forest enterprise to operate in woodlands that lack roads and infrastructure, as well as overcoming problems with uneven terrain, which can reduce the income from operations. The reduced investment costs could also allow their use for the production of firewood or in areas where the level of mechanisation is not widespread and still at an early stage.

Table 6. Regression model parameters for Larix Lamako.

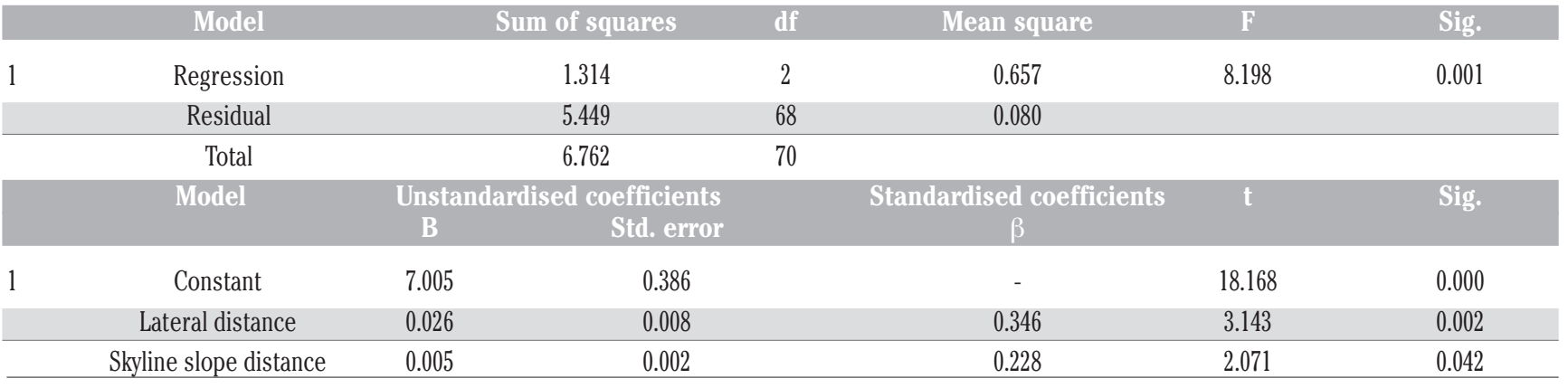

df, degree of freedom; Sig., significance; Std. error, standard error. 


\section{References}

Ackerman P., Belbo H., Eliasson L., De Jong A., Lazdins A., Lyons J. 2014. The COST model for calculation of forest operations costs. Int. J. For. Eng. 25:75-81.

Aykut T. 1986. The used cable systems at transporting of forest. I.U. Review of the Faculty of Forestry 36:53-71.

Balimunsi H., Grigolato S., Picchio R., Nyombi K., Cavalli R. 2012. Productivity and energy balance of forest plantation harvesting in Uganda. For. Stud. China 14:276-82.

Borz S.A., Bîrda M., Ignea G., Popa V.R., Câmpu Iordache E., Derczeni R. 2014. Efficiency of a Woody 60 processor attached to a Mounty 4100 tower yarder when processing coniferous timber from thinning operations. Ann. For. Res. 57:333-45.

Cavalli R. 2012. Prospects of research on cable logging in forest engineering community. Croat. J. For. Eng. 33:339-56.

Cosola G., Grigolato S., Ackerman P., Monterotti S., Cavalli R. 2016. Carbon footprint of forest operations under different management regimes. Croat. J. For. Eng. 37:201-17.

Heinimann H.R., Stampfer K., Loschek J., Caminada L. 2001. Perspectives on central European cable yarding systems. pp 268279 in Proc. 1th International Mountain Logging and 11th Northwest Pacific Skyline Symposium, Seattle, Washington, USA.

Holzleitner F., Stampfer K., Visser R. 2011. Utilization rates and cost factors in timber harvesting based on long-term machine data. Croat. J. For. Eng. 32:501-8.

Hurt V., erný J., Albrechtová P. 2014. Natural mortality in beech-larchoak-hornbeam forest stands on a nutrient-rich site at Training Forest Enterprise Masaryk Forest K tiny (TFE) in the southern Moravia Region/Czech Republic. Forstarchiv. 85:115-21.

Huyler N.K., Ledoux C.B. 1997. Cycle-Time equation for the Koller K300 cable yarder operating on steep slopes in the Northeast. Res. NE705. USDA, Delaware, OH, USA.
Klun J., Piškur M., Medved M. 2005. Efficiency of cable yarding in Slovenian state forests. pp 184-191 in Proc. XXXIIX Congr. FORMEC, Ljubljana, Slovene.

Klva R., Fischer R., Skoupý A. 2012. Energy use of and emissions from the operation phase of a medium distance cableway system. Croat. J. For. Eng. 33:79-88.

Kovácik P., Stoiloiv S. 2009. Standing skyline yarding systems larix in thinnings and selection silvicultural systems. pp 36-38 in Proc. Innov. Woodwork. Ind. Eng. Des., Sofia, Bulgaria.

Mayr-Melnhof Forsttechnik GmbH, 2009. Sherpa universal carriage. Available from: http:/www.mm-forsttechnik.at/forsttechnik/ download/Sherpa_englisch.pdf

Miyata E.S. 1980. Determining fixed and operating costs of logging equipment. For. Serv. G. Tech. Rep., pp. 14.

Ozturk T., Senturk N. 2006. Extraction of spruce timber by Gantner cable crane from selective forests of Artvin region. Croat. J. For. Eng. 27:59-66.

Philip M.S. 1994. Measuring trees and forests. 2th rev ed. CAB International, Wallingford, UK, pp. 336.

Proto A.R., Zimbalatti G. 2015. Firewood cable extraction in the southern Mediterranean area of Italy. For. Sci. Tech. 20:1-8.

Spinelli R., Magagnotti N., Lombardini C. 2010. Performance, capability and costs of small-scale cable yarding technology. Small-scale For. 9:123-35.

Stampfer K., Visser R., Kanzian C. 2006. Cable corridor installation times for European yarders. Int. J. For. Eng. 17:71-7.

Stanczykiewicz A., Szewczyk G., Kulak D. 2015. Damage to advance growth resulting from timber harvesting during final cuttings. Balt. For. 21:144-51.

Worrell W.C., Bolding M.C., Aust W.M. 2011. Potential soil erosion following skyline yarding versus tracked skidding on bladed skid trails in the Appalachian region of Virginia. Southern J. App. For. 35:131-5.

Zimbalatti G., Proto A.R. 2009. Cable logging opportunities for firewood in Calabrian forests. Biosys. Eng. 102:63-8. 